\section{Sound of erudition}

\section{James Cullen}

Science and Civilisation in China, Vol. 6: Part 1. Biology and Biological Technology: Botany. By Joseph Needham. Cambridge University Press: 1986. Pp.718. £50, \$95.

DR NeEDHAM's series Science and Civilisation in China, which he began some 30 years ago, needs little introduction here. This latest volume is by Needham himself, with the collaboration of Li Gwei Djen (Cambridge) and Huang Hsing-Tsung (Washington). Part 2 of Vol. 6, Agriculture, by Francesca Bray, was published in 1984 , and a further part, continuing the subject of botany, is being prepared by Georges Métailié of the Musée d' Histoire Naturelle in Paris.

In covering the history of botany in China from its remote origins to the impact on it of Western science in the late nineteenth century, Needham has surveyed a huge amount of literature. There are three bibliographies - of Chinese and Japanese books before 1800 ; the same since 1800; and books and articles in Western languages - which altogether occupy 99 pages. This vast quantity of source material is processed with a breathtaking display of erudition.

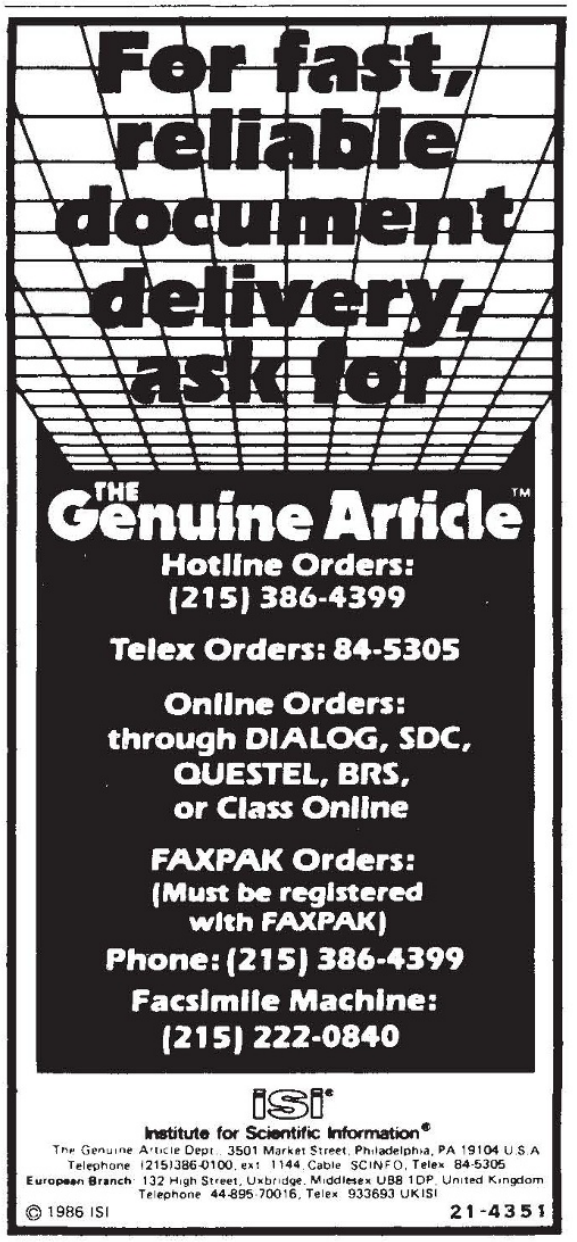

Throughout, Needham contrasts what was happening botanically in China with corresponding events in the West, and stresses two important differences: first, that the history of botany in China, like that of many of the physical sciences, is more continuous than in the West - in China there were difficult times, but no aching void equivalent to the Dark Ages; second, following the rapid advance of the scientific method in the West, Western botany overtook Chinese in both the pace and scope of its development. Needham categorizes Chinese botanical taxonomy (for the volume is, by necessity, mainly a history of taxonomy) as having reached a "Magnolian" or "Tournefortian" rather than a "Linnaean" or "post-Linnaean" level.

After the introduction, the volume is divided into five large sections. The first, "The Setting: China's Plant Geography", is a brief survey of the floristic divisions of the country as recognized by botanists today, together with a discussion of the development of Chinese ideas on the topic in which the stress is on soils and soil types.

The second section, "Botanical Linguistics", covers Chinese terminology for plant description and nomenclature. This fascinating if complex subject is clearly presented for those who know little about ideographic writing. Needham concludes it with some thoughts on the appropriateness of ideographs for taxonomic purposes. Because they are made up of superimposed radicals, ideographs can convey classificatory ideas very satisfactorily ("it might well be said that a language the dictionaries of which have to be based on taxonomic principles is a language remarkably congruent with the nature of biology" - p.178); indeed, Needham compares them with various coding systems (some of them machine-readable) developed in recent years.

"The Literature and its Contents" follows and is the heart of the volume. A wide variety of texts is surveyed for their botanical content, including lexicographic and encyclopaedic works, medical books, books on wild (emergency) food plants, monographs and tractates, and works on historical and exotic botany. This section is too densely packed to describe in any detail, but one of its most interesting topics is that of the monographs: some little knowledge of these has filtered through to Western botanists, but their age-range and scope are not so well known. Monographs on citrus fruits (Citrus, Fortunella), bamboos (Gramineae Bambusoideae), peonies (Paeonia) and chrysanthemum, among others, are discussed in some detail; the amount of study devoted by the Chinese to cultivated varieties is noteworthy.

The final section deals with a less narrowly taxonomic subject, that of pest control among cultivated plants, and in particular the use of biological control in agriculture. Entitled "Plants and Insects in Man's Service", it is by Huang HsingTsung and contains much of interest, especially the account of the use of a species of ant (Oecophylla smaragdina) to control pests in orange orchards, with the use of bamboo bridges from tree to tree to "facilitate migration". This means of control appears to have been in consistent use in South China from AD 300 to 1960 . Its effectiveness is, however, doubted by

IMAGE
UNAVAILABLE
FOR
COPYRIGHT
REASONS

Aquatic frog (wa) - detail of an illustration in Paul U. Unschuld's Medicine in China: A History of Pharmaceutics, newly published by University of California Press. Price is \$47.50, £40.50.

some authorities, both Chinese and Western.

The whole book is a pleasure to read: informative, stimulating and written with a wit and passion that are found more often in historical than botanical texts. Needham expects quite a lot of his readers: on p.373, quoting a long passage from Han Yen-Chih's Chü $L u$, the footnote to part of it reads:

The sentences in inverted commas were, as Pelliot recognised, borrowed by Han Yen-Chih from a Letter accompanying a Present of Oranges' written by Liu Hsun.... He worked them in, as they were appropriate, just as we might use a few words of Sir Thomas Browne, knowing that all educated readers would respond to the echo.

How many botanists might so respond? However few, the book contains so much valuable "sound" that the loss of a few echoes is not significant.

James Cullen is Assistant Keeper of the Royal Botanic Garden, Inverleith Row, Edinburgh EH3 $5 L R, U K$. 